\title{
Muricauda ruestringensis gen. nov., sp. nov., a facultatively anaerobic, appendaged bacterium from German North Sea intertidal sediment
}

\author{
1,3 Institut für Chemie und \\ Biologie des Meeres ${ }^{1}$ and \\ Fachbereich Biologie, \\ Geo- und \\ Umweltwissenschaften ${ }^{3}$, \\ C. v. O. Universität \\ Oldenburg, PO Box 2503 , \\ D-26111 Oldenburg, \\ Germany \\ 2 Bereich Mikrobiologie, \\ Abt. Mikrobielle \\ Pathogenität und \\ Impfstoffforschung, \\ GBF - Gesellschaft für \\ Biotechnologische \\ Forschung, Mascheroder \\ Weg 1, D-38124 \\ Braunschweig, Germany
}

\author{
Alke Bruns, ${ }^{1}$ Manfred Rohde ${ }^{2}$ and Luise Berthe-Corti ${ }^{3}$ \\ Author for correspondence: Luise Berthe-Corti. Tel: +49441798 3290. Fax: +494417983250. \\ e-mail: Luise.Berthe.Corti@uni-oldenburg.de
}

\begin{abstract}
A Gram-negative, facultatively anaerobic bacterium with appendages was isolated from continuous cultures with a seawater-sediment suspension containing hexadecane as the sole carbon source. Although this organism was isolated from a hexadecane-degrading bacterial community, it was not able to degrade hexadecane. However, this bacterium was able to use different sugars and amino acids for growth, indicating that it probably profits from the lysis or from products like surfactants of other cells in the community. 16S rDNA analysis demonstrated that the isolated strain is phylogenetically related to the family Flavobacteriaceae of the phylum ' Cytophaga-FlavobacteriumBacteroides'. Evidence based on phenotypic characteristics and 16S rDNA analysis supports the conclusion that this bacterium is distinct from its nearest relative, Zobellia uliginosa ( $90.72 \%$ similarity in $16 \mathrm{~S}$ rRNA gene sequence), and from the other genera of the Flavobacteriaceae. It is therefore proposed that the isolated marine bacterium represents a novel taxon, designated Muricauda ruestringensis gen. nov., sp. nov. The type strain is strain $\mathrm{B1}^{\top}\left(=\mathrm{DSM} 13258^{\top}=\right.$ LMG 19739').
\end{abstract}

Keywords: Muricauda ruestringensis, Flavobacteriaceae, facultative anaerobe, marine bacterium, appendages

\section{INTRODUCTION}

Members of the order [Cytophagales] are ubiquitous and probably play a major role in the turnover of organic matter, since they are able to degrade natural polymers, e.g. starch, cellulose or gelatin (Reichenbach, 1992). Many marine species belonging to this order can use cell-wall components and exudates from macroalgae as nutrient sources (Johansen et al., 1999). In addition to enhanced nutrient concentrations when living next to or as an epiphyte of phytoplankton, phytoplankton is available as a surface for colonization (Bowman et al., 1997b). The ecological importance of the [Cytophagales] is confirmed by in situ hybridization data that show the great abundance $(20-70 \%$ of the total bacterial biomass) of members of this order in the coastal pelagic zone of Antarctica (Glöckner et al., 1999). Members of this group were found in all marine and freshwater

The GenBank accession number for the $16 \mathrm{~S}$ rDNA sequence of $\operatorname{strain} B 1^{\top}$ is AF218782. samples investigated by Glöckner et al. (1999) and they usually formed the largest bacterial group in marine water. In recent studies, these bacteria have also been detected in intertidal sediments, where they represent a large part of the natural microbial community (LlobetBrossa et al., 1998; Bruns \& Berthe-Corti, 1998). Most of the recently described genera of the Flavobacteriaceae, e.g. Psychroserpens and Gelidibacter (Bowman et al., 1997a), Psychroflexus (Bowman et al., 1998), Polaribacter (Gosink et al., 1998) and Cellulophaga (Johansen et al., 1999), were isolated from marine environments, demonstrating that this seems to be an important habitat for members of the [Cytophagales].

Many studies within the last two decades have demonstrated the high degree of biological diversity of the order [Cytophagales] with respect to phenotypic characterization, fatty acid composition and phylogenetic analysis (Johansen et al., 1999). Reichenbach (1989a) was also aware of the confusing nomenclature when stating that 'at the moment we do not yet know enough to clearly recognize the boundaries of the 
order Cytophagales or to define other orders'. Today, the diversity of the [Cytophagales] is accepted and this has resulted in several reclassifications. Many members of the genus Cytophaga have been reclassified within the genus Flavobacterium (Bernardet et al., 1996). In contrast to the former description of Flavobacterium as containing non-motile and non-gliding species, the emended genus represents predominantly gliding bacteria (Bernardet et al., 1996). Nakagawa \& Yamasato (1996) revealed by $16 \mathrm{~S}$ rDNA analysis that the genera Cytophaga, Flavobacterium and Flexibacter are polyphyletic. These authors suggested that Cytophaga hutchinsonii and Cytophaga aurantiaca are the only genuine Cytophaga species that are able to decompose crystalline cellulose. The second edition of Bergey's Manual of Systematic Bacteriology (http:// www.cme.msu.edu/Bergeys/index.html), publication of which has begun in 2001, also takes these results into account and suggests the new orders 'Flavobacteriales' and 'Sphingobacteriales', while the order [Cytophagales] will no longer exist in the new edition.

We isolated and characterized several strains from a series of marine enrichment cultures. One of these strains, isolate $\mathrm{B} 1^{\mathrm{T}}$, originates from intertidal sediment taken from the German North Sea coast that was cultivated in a continuous culture containing only hexadecane as a source of carbon and energy. Despite the added carbon source, strain $\mathrm{B} 1^{\mathrm{T}}$ does not degrade hexadecane and seems to play another role in the community of the continuous culture. 16S rDNA analysis revealed that strain $\mathrm{B} 1^{\mathrm{T}}$ is affiliated with the Flavobacteriaceae and its closest relative is Zobellia uliginosa. In this study, we describe the new strain and analyse its relationship to members of the Flavobacteriaceae.

\section{METHODS}

Strain cultivation. Strain $\mathrm{B} 1^{\mathrm{T}}$ was isolated from a continuousflow culture with sediment originating from the German Wadden Sea (Jadebusen Bay), as described previously (Bruns \& Berthe-Corti, 1999). Cultivation was performed routinely on solid modified nutrient agar containing $0.25 \%$ $(\mathrm{w} / \mathrm{v})$ Bacto Peptone (Difco), 0.15\% (w/v) yeast extract, $0.2 \%(\mathrm{v} / \mathrm{v})$ hexadecane, $1.5 \%(\mathrm{w} / \mathrm{v})$ agar in artificial seawater with reduced salinity $(2 \cdot 25 \%)$. The artificial seawater contained $\left(1^{-1}\right.$ distilled water $): 23.6 \mathrm{~g} \mathrm{NaCl} ; 0.64 \mathrm{~g}$ $\mathrm{KCl} ; 4.53 \mathrm{~g} \mathrm{MgCl}_{2} .6 \mathrm{H}_{2} \mathrm{O} ; 5.94 \mathrm{~g} \mathrm{MgSO}_{4} .7 \mathrm{H}_{2} \mathrm{O} ; 1.3 \mathrm{~g}$ $\mathrm{CaCl}_{2} \cdot 2 \mathrm{H}_{2} \mathrm{O}$ (Levring, 1946). In order to avoid precipitation, the $\mathrm{CaCl}_{2} \cdot \mathrm{H}_{2} \mathrm{O}$ was sterilized separately. The $\mathrm{pH}$ of the medium was adjusted with $\mathrm{NaHCO}_{3}$ to $7 \cdot 2$ and incubation was carried out at $25^{\circ} \mathrm{C}$. For some phenotypic characterizations, the organism was cultivated on several other media, which are described below.

Phenotypic characterization. The bathochromic shift test with $20 \%(\mathrm{w} / \mathrm{v}) \mathrm{KOH}$ was performed to detect flexirubintype pigments (Fautz \& Reichenbach, 1980). For this purpose, some biomass was deposited on a slide and covered with $\mathrm{KOH}$. If the test is positive, the colour of the biomass changes from yellow to red, purple or red-brown when $\mathrm{KOH}$ is added and back to yellow again when the latter is replaced with $10 \%(\mathrm{v} / \mathrm{v}) \mathrm{HCl}$. The ability to grow with different carbon sources was analysed in a seawater medium (SWM; Bruns \& Berthe-Corti, 1999) supplemented with $0 \cdot 1 \%(\mathrm{w} / \mathrm{v})$ of the tested carbon source or with strips of filter paper for testing cellulolytic activity. Growth with peptone as the sole carbon source was performed on a solid medium containing $0 \cdot 25 \%(\mathrm{w} / \mathrm{v})$ peptone in artificial seawater of $2 \cdot 25 \%$ salinity, $\mathrm{pH}$ 7.2. Agar degradation was studied on SW2 agar (Reichenbach, 1992). Acid production from fructose was studied as described by Smibert \& Krieg (1994) using Hugh \& Leifson's $\mathrm{O} / \mathrm{F}$ medium (containing only $\mathrm{NaCl}$ and $\mathrm{KH}_{2} \mathrm{PO}_{4}$ as salts) and with Leifson's modified $\mathrm{O} / \mathrm{F}$ medium, which contains artificial seawater. Analysis of gliding motility was performed on a low-concentration nutrient medium containing $0.052 \%(\mathrm{w} / \mathrm{v})$ peptone, $0.03 \%(\mathrm{w} / \mathrm{v})$ meat extract and $0.9 \%(\mathrm{w} / \mathrm{v})$ agar in artificial seawater $(2.25 \%$ salinity), $\mathrm{pH} 7 \cdot 2$ at $30^{\circ} \mathrm{C}$, under high moisture conditions, as recommended by Wolkin \& Pate (1984). Starch and gelatin hydrolysis were analysed using PAC medium (see fatty acid analysis) supplemented with $0.2 \%(\mathrm{w} / \mathrm{v})$ starch or $0.4 \%$ gelatin, respectively. Indole production was tested as described by Smibert \& Krieg (1994) using PAC medium supplemented with $0.01 \%(\mathrm{w} / \mathrm{v})$ L-tryptophan. Production of $\mathrm{H}_{2} \mathrm{~S}$ was studied as described previously (Smibert \& Krieg, 1994) using a medium containing $0.25 \%(\mathrm{w} / \mathrm{v})$ peptone, $0.15 \%(\mathrm{w} / \mathrm{v})$ meat extract, $0.015 \%(\mathrm{w} / \mathrm{v})$ sodium thiosulfate, $0.027 \%(\mathrm{w} / \mathrm{v}) \mathrm{FeSO}_{4} \cdot 7 \mathrm{H}_{2} \mathrm{O}$ and $1.5 \%(\mathrm{w} / \mathrm{v})$ agar in artificial seawater of $2 \cdot 25 \%$ salinity, described above. Tolerance of different $\mathrm{NaCl}$ concentrations was tested in the synthetic medium described by Gauthier et al. (1992), which contained $1 \cdot 23 \%(\mathrm{w} / \mathrm{v})$ Tris, $0 \cdot 37 \%(\mathrm{w} / \mathrm{v}) \mathrm{MgSO}_{4} .7 \mathrm{H}_{2} \mathrm{O}$, $0.15 \%(\mathrm{w} / \mathrm{v}) \mathrm{CaCl}_{2}$ and $0.075 \%(\mathrm{w} / \mathrm{v}) \mathrm{KCl}$. All of the inoculated media described above were incubated at $30{ }^{\circ} \mathrm{C}$.

Further tests used to characterize the phenotype of the strain have been described in a previous paper (Bruns \& BertheCorti, 1999).

In order to examine their denitrification ability, cells were grown anaerobically under a helium atmosphere in a modified liquid nutrient broth containing $0.3 \%$ acetate and $0 \cdot 1 \%$ (w/v) $\mathrm{KNO}_{3}$ (nitrate was labelled with the ${ }^{15} \mathrm{~N}$ isotope). The formation of nitrite was tested after $4,8,13$ and $17 \mathrm{~d}$ of incubation at $30{ }^{\circ} \mathrm{C}$ using MERCKOQUANT sticks (Merck). The production of gaseous ${ }^{15} \mathrm{~N}$ nitrogen compounds was analysed on a type MAT 95 mass spectrophotometer (Finnigan MAT), applying the electronionization method (electron energy $70 \mathrm{eV}$, source temperature $220{ }^{\circ} \mathrm{C}$; Budzikiewicz, 1998).

Electron microscopy. For negative staining, samples were absorbed onto carbon film, washed in TE buffer $(0.02 \mathrm{M}$ Tris $/ \mathrm{HCl}, 0.001 \mathrm{M}$ EDTA, $\mathrm{pH} 6.9)$, stained with $4 \%(\mathrm{w} / \mathrm{v})$ aqueous uranyl acetate ( $\mathrm{pH} 4 \cdot 5)$ according to the method of Valentine et al. (1968) and picked up with 300-mesh copper grids. After air-drying, samples were examined in a Zeiss EM910 or EM109 transmission electron microscope (TEM) at an acceleration voltage of $80 \mathrm{kV}$ and at calibrated magnifications.

For scanning electron microscopy (SEM), strain $\mathrm{B} 1^{\mathrm{T}}$ was fixed on ice for $1 \mathrm{~h}$ in a fixation solution containing $3 \%(\mathrm{v} / \mathrm{v})$ formaldehyde and $2 \%(\mathrm{v} / \mathrm{v})$ glutaraldehyde. After three washing steps with PBS, samples were absorbed onto polyL-lysine-coated cover slips and fixed with $3 \%$ (v/v) glutaraldehyde in TE buffer for $10 \mathrm{~min}$ at room temperature, washed with TE buffer, dehydrated in a graded series of acetone and subjected to critical-point drying with liquid $\mathrm{CO}_{2}$. Samples were then covered with an approximately $10 \mathrm{~nm}$ thick gold film and examined with a field emission SEM (Zeiss DSM 
982 Gemini) using the Everhart Thornley SE detector and the inlens detector at a ratio of 50:50.

For TEM, samples were fixed with the same fixation solution, pelleted and embedded into $1.5 \%(\mathrm{w} / \mathrm{v})$ agar in cacodylate buffer $(0 \cdot 1 \mathrm{M}$ sodium cacodylate, $0.09 \mathrm{M}$ sucrose, $\left.0.005 \mathrm{M} \mathrm{CaCl}_{2}, \mathrm{pH} 6 \cdot 9\right)$. Samples were fixed and contrasted with $1 \%(\mathrm{w} / \mathrm{v})$ osmium tetroxide for $1 \mathrm{~h}$ at room temperature and $4 \%(\mathrm{w} / \mathrm{v})$ uranyl acetate overnight. After dehydration with a graded series of ethanol, samples were embedded in LRWhite resin. After polymerization of the resin $\left(50{ }^{\circ} \mathrm{C}, 1-2 \mathrm{~d}\right)$, ultrathin sections were cut with a diamond knife, counterstained with lead citrate and uranyl acetate and examined in a Zeiss EM910 microscope.

For the determination of anionic sites on the bacterial surface and appendages, fixed samples were treated with TE buffer, $\mathrm{pH} 2 \cdot 5$, for $10 \mathrm{~min}$ and then incubated with cationic gold (gold particle size of $15 \mathrm{~nm}$ ) for $15 \mathrm{~min}$ at room temperature, washed with the TE buffer and absorbed onto carbon film. The carbon film was picked up with 300-mesh copper grids and samples were stained with $4 \%(\mathrm{w} / \mathrm{v})$ aqueous uranyl acetate before examination in the TEM.

Fatty acid analysis. To obtain biomass for fatty acid analysis, strain $\mathrm{B} 1^{\mathrm{T}}$ was grown in a liquid PAC medium containing: $0 \cdot 1 \%$ (w/v) $\mathrm{CH}_{3} \mathrm{COCOONa}, 0 \cdot 416 \%$ (w/v) $\mathrm{CH}_{2} \mathrm{COONa}$, $0.1 \%$ Casamino acids, $3 \mathrm{ml}$ vitamin solution (Schlegel, 1992), $1 \mathrm{ml}$ mineral salt solution (DSMZ medium no. 124), $0 \cdot 146 \%(\mathrm{w} / \mathrm{v}) \mathrm{NaNO}_{3}$ and $0 \cdot 14 \mathrm{~g} \mathrm{Na}_{2} \mathrm{HPO}_{4}$ in artificial seawater of $2 \cdot 25 \%$ salinity, $\mathrm{pH} 7 \cdot 2$. The incubation was performed at $30^{\circ} \mathrm{C}$. To prepare the esters for GC analysis, harvested cells were saponified, methylated, extracted and washed with $0 \cdot 24 \mathrm{M} \mathrm{NaOH}$ according to the procedure of the SHERLOCK microbial identification system (MIDI). The extracted fatty acid methyl esters were chromatographed on an apolar capillary column (HP-Ultra2, $25 \mathrm{~m}$, $0.22 \mathrm{~mm}$; Hewlett Packard) with helium as the carrier gas. The analysis was carried out with an HP 5890 series II gas chromatograph (split-less injection, temperature between 170 and $310^{\circ} \mathrm{C}$, flame-ionization detector) with peak integration by the HP3365 ChemStation software. Esters were identified using known internal standards.

DNA base composition. Genomic DNA was extracted from strain $B 1^{\mathrm{T}}$ and then analysed using the HPLC method as described by Mesbah et al. (1989).

$16 \mathrm{~S}$ rDNA sequencing and analysis. The $16 \mathrm{~S}$ rDNA gene sequence was determined by Sequence Laboratories Göttingen (Seqlab, Germany). The genomic DNA was extracted as described by Sambrook et al. (1989). For amplification of the $16 \mathrm{~S}$ rDNA, primers M13Fgm3F (5'TGTAAAACGACGGCCAGTTAGAGTTTGATCMTGGC-3') and M13Rgm4R (5'-CAGGAAACAGCTATGACCTTACCTTGTTACGACTT-3') were used, which were coupled to the $16 \mathrm{~S}$ rDNA-specific primers GM3F (positions 8-24 according to Escherichia coli numbering) and GM4R (positions 1492-1507) (Muyzer et al., 1995). PCR amplification was performed with 35 cycles of $96^{\circ} \mathrm{C}$ for $20 \mathrm{~s}, 60^{\circ} \mathrm{C}$ for $60 \mathrm{~s}$ and $72^{\circ} \mathrm{C}$ for $90 \mathrm{~s}$. The sequencing reaction was performed using the ABI Dye Terminator technology according to the manufacturer (Applied Biosystems). An Applied Biosystems model 377 DNA sequencer was used for electrophoresis of the sequence reaction mixtures.

The 16S rDNA sequence was compared to sequences from GenBank using the program BLASTN 2.0 (Altschul et al.,
1997) available through the National Center for Biotechnology Information (NCBI) internet site. Sequences of other members of the Flavobacteriaceae were downloaded and aligned with the $16 \mathrm{~S}$ rDNA sequence of strain $\mathrm{B} 1^{\mathrm{T}}$ using CLUSTAL W (Thompson et al., 1994).

Evolutionary distances were calculated by the method of Jukes \& Cantor (1969) and a phylogenetic tree was constructed by the neighbour-joining method (Saitou \& Nei, 1987) using the program MEGA (Kumar et al., 1994).

\section{RESULTS}

\section{Cell and colony morphology}

Strain $\mathrm{B} 1^{\mathrm{T}}$ is a Gram-negative, non-motile organism. Cells grown in PAC medium were rod-shaped with rounded ends, $0 \cdot 3-0 \cdot 6 \mu \mathrm{m}$ wide and $1 \cdot 1-2 \cdot 7 \mu \mathrm{m}$ long (Fig. 1a). Ultrathin sections showed the typical ultrastructure of a Gram-negative bacterium (Fig. 1g). One main characteristic, however, was the formation of holes in the outer membrane in older cultures (Fig. 1h). Cells of older cultures (3-4d) were characterized by long and relatively thick $(20-35 \mathrm{~nm})$, mostly polarlocated appendages (Fig. 1a-c; Fig. 2). However, not all of the cells produced such appendages. Appendages were often characterized by vesicle-like structures at the end, which exhibited fibrillar-like structures on the surface (Fig. 1c). Ultrathin sections revealed that the appendages are formed as a continuum of the outer membrane (Fig. 1i) and are covered by a membrane (Fig. 1f). We assume that these appendages are used to connect cells with each other (Fig. 1a), since we observed that cells grew mostly in small flocks in older cultures. Another explanation might be that these structures are used for colonization of a given substratum, because strain $\mathrm{B} 1^{\mathrm{T}}$ was able to colonize glass beads easily. The use of cationic gold particles allowed us to determine whether or not anionic components of the outer membrane are involved in the formation of appendages. During the early formation of appendages (Fig. 1d), we could demonstrate that more anionic sites were exposed in this process compared with anionic sites on the remaining cell surface. Furthermore, the entire appendage and the vesicle-like structure at its end was covered with numerous anionic sites (Fig. 1e).

This organism produced colonies (diameter 0.5$1.0 \mathrm{~mm}$ ) on modified nutrient agar that were yellow in colour, circular and convex in shape with regular edges. Strain $\mathrm{B} 1^{\mathrm{T}}$ has no flexirubin-type pigment, as determined by the bathochromic shift test. Colonies with shapes other than those with a regular edge but with a halo of fine hairy roots were observed only after 3 weeks of incubation on low-concentration nutrient medium under high-moisture conditions. This halo contains cells. However, the colonies do not show the typical spread shape of the edges, as demonstrated for gliding cells of [Flexibacter] filiformis and Flavobacterium columnare (formerly [Cytophaga columnaris]) (Reichenbach, 1992). Cells were nonmotile in hanging-drop preparations; they showed 

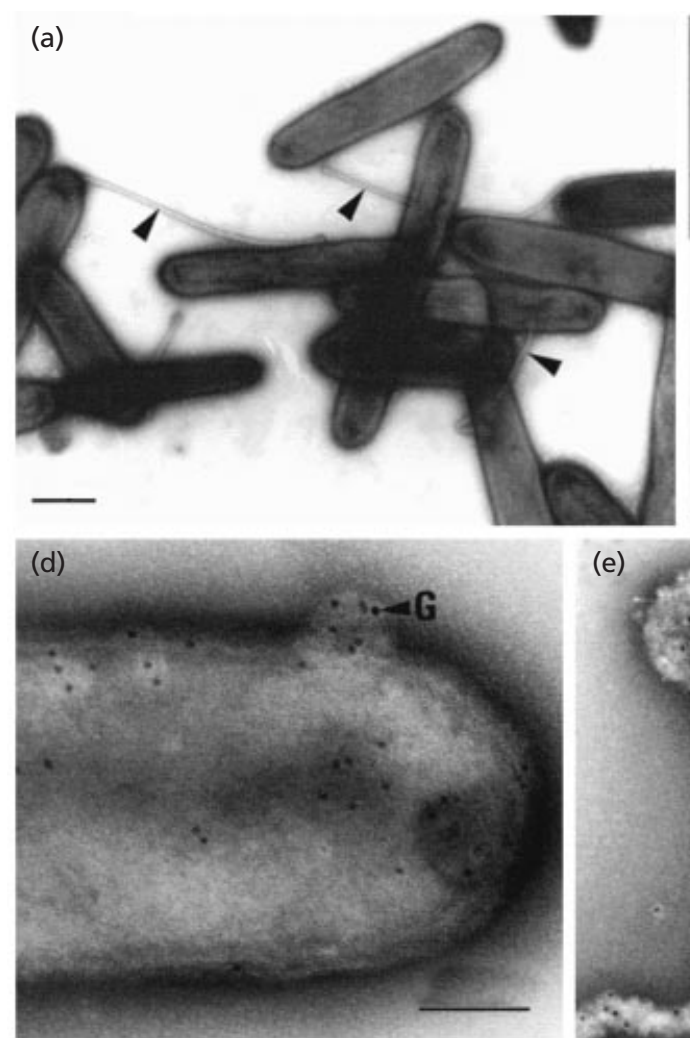

(e)
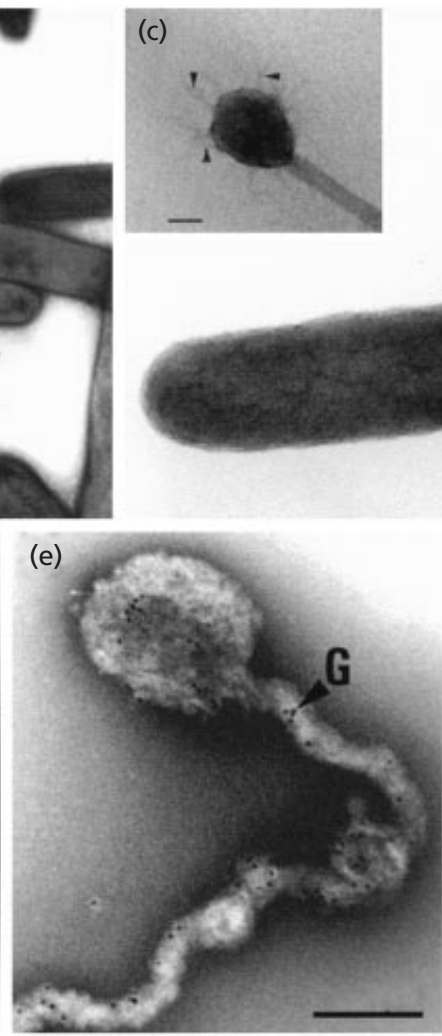

(f)
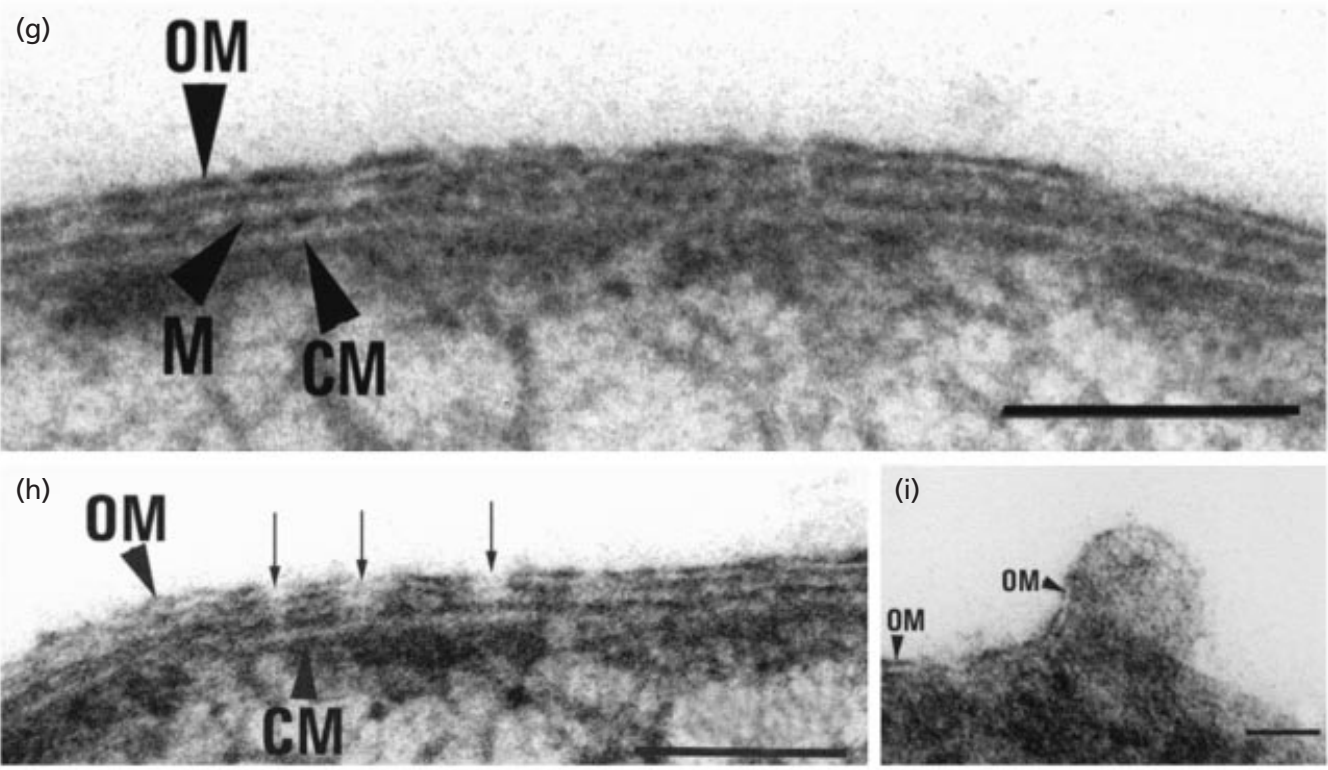

(i)

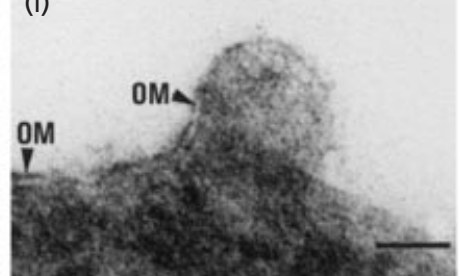

Fig. 1. Transmission electron micrographs showing the cell morphology and ultrastructure of $M$. ruestringensis strain $B 1^{\top}$. (a)-(e) Negative staining of cells. Arrowheads mark appendages, which can be seen in small flocks of the bacteria (a). (b) and (c) show an appendage on a single cell and the characteristic vesicle-like structure at the end with fibrillar-like structures. Arrowheads in (d) and (e) show localization of anionic structures with cationic gold particles (G) on the bacterial surface and the appendages. (f)-(i) Ultrathin sections showing ultrastructural features. (g) Typical Gramnegative arrangement of the cell periphery of a young bacterial cell with a cytoplasmic membrane (CM), murein (M) and outer membrane (OM). Older cultures were characterized by several holes in the outer membrane (arrows in $h$ ). Appendages are formed at first as a continuum of the outer membrane (i) and exhibit a typical membrane structure when fully grown (f). Bars, $0.5(a, b), 0.2(d, e), 0.1(f-h)$ and $0.05(c, i) \mu \mathrm{m}$. 

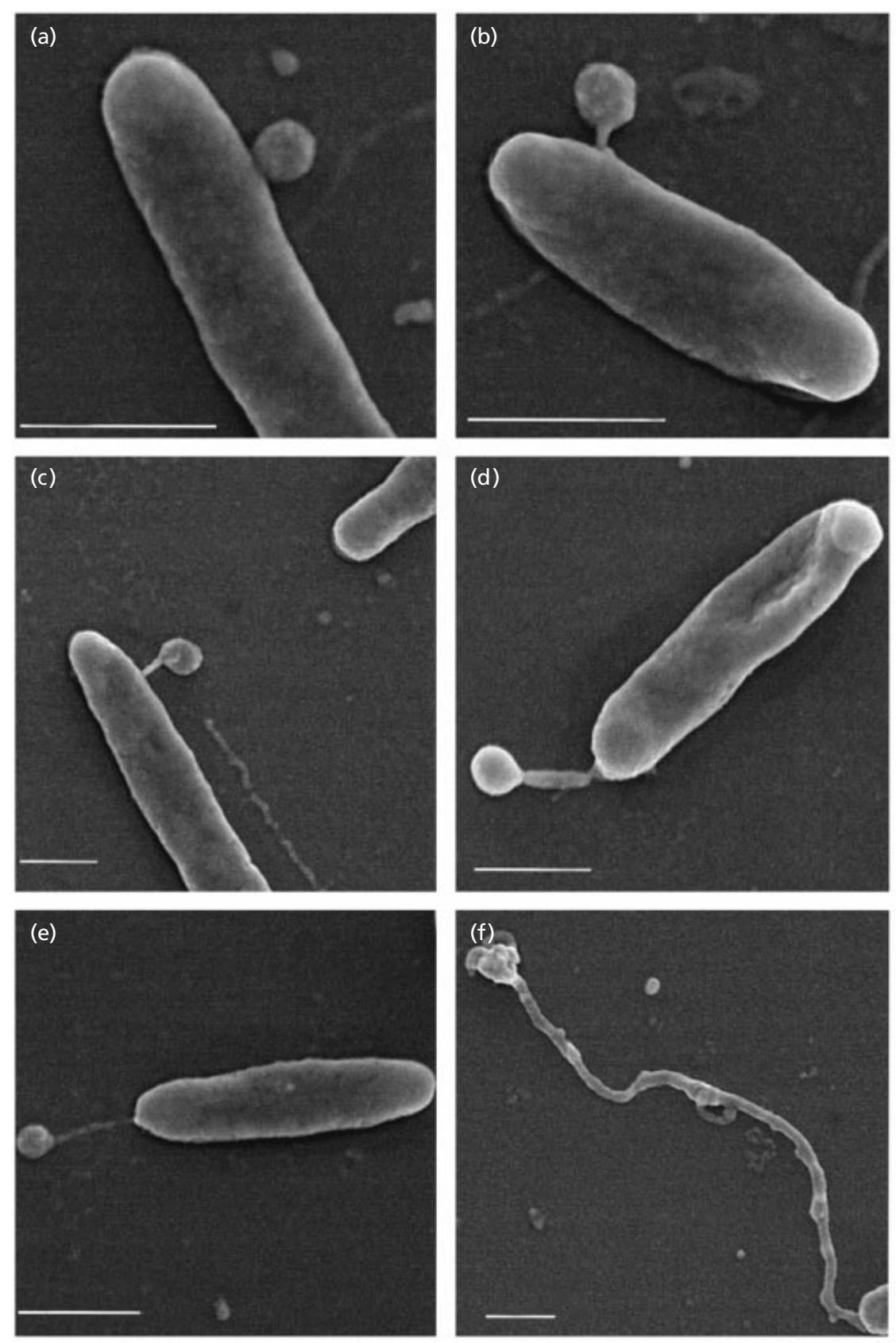

Fig. 2. Scanning electron micrographs of appendage formation in $M$. ruestringensis strain $B 1^{\top}$. Appendage formation probably starts with the building of vesicle-like structures (blebs) on the bacterial surface (a), which then grow behind the vesicle-like structures up to a length of approximately $5 \mu \mathrm{m}(\mathrm{b}-\mathrm{f})$. Bars, $0.5 \mu \mathrm{m}$.

neither swimming nor gliding motility as defined by Henrichsen (1972).

\section{Growth properties}

Strain $B 1^{\mathrm{T}}$ is a facultatively anaerobic, seawaterrequiring chemoheterotroph. The organism is able to grow aerobically and grows weakly under anaerobic conditions. It is slightly halophilic, showing good growth in media containing $0 \cdot 5-9 \cdot 0 \%(\mathrm{w} / \mathrm{v}) \mathrm{NaCl}$, with optimal growth at $3 \%(\mathrm{w} / \mathrm{v}) \mathrm{NaCl}$. The $\mathrm{pH}$ tolerance ranges between $\mathrm{pH} 6 \cdot 0$ and $8 \cdot 0$; the optimum for growth is $\mathrm{pH} 6 \cdot 5-7 \cdot 5$. The strain has a wide temperature range for growth, showing growth between 8 and $40{ }^{\circ} \mathrm{C}$, with optimal growth between 20 and $30^{\circ} \mathrm{C}$.

\section{Physiology and metabolism}

The physiological characteristics of strain $\mathrm{B} 1^{\mathrm{T}}$ are summarized in Tables 1 and 2. The organism was isolated from a continuous-flow culture, containing 
Table 1. Growth of strain $B 1^{\top}$ with different carbon sources

Growth is scored as: +, turbidity; - , no turbidity. The amino acid mixtures contained the following amino acids (each at $200 \mu \mathrm{M}): 1$, alanine, arginine, asparagine and cysteine; 2, glutamine, glutamic acid, glycine and histidine; 3 : isoleucine, leucine, lysine and methionine; 4 , phenylalanine, proline and serine; 5 , tryptophan, tyrosine and valine; 6 , all 19 amino acids contained in mixtures $1-5$.

\begin{tabular}{|lc|}
\hline Substrate & Growth \\
\hline Raffinose & + \\
Cellobiose & + \\
Sucrose & + \\
Lactose & + \\
Glucose & - \\
Fructose & + \\
Mannose & + \\
Acetate & - \\
Pyruvate & - \\
Alanine & + \\
Arginine & + \\
Serine & - \\
Ethanol & - \\
Mannitol & - \\
Hexadecane & - \\
Amino acid mixtures: & \\
1 & + \\
2 & + \\
3 & + \\
4 & + \\
5 & + \\
6 & + \\
& \\
\end{tabular}

mud-flat sediment and hexadecane as the sole source of carbon at a low oxygen concentration $(0.4 \%$ DOT, equivalent to $0 \cdot 8 \mu \mathrm{mol} \mathrm{O}_{2} 1^{-1}$ ). However, it showed no growth with hexadecane as the sole source of carbon. Hexadecane was also not used when it was offered in combination with other carbon sources such as lactose, fructose or a mixture of the 20 amino acids. Furthermore, strain $\mathrm{B} 1^{\mathrm{T}}$ was unable to use pyruvate or acetate when these compounds were offered as the sole carbon source. The other substrates that strain $\mathrm{B} 1^{\mathrm{T}}$ used for growth are listed in Table 1. It was able to grow with a wide spectrum of different amino acids as sole carbon and energy sources. In contrast to related halophilic organisms of the Flavobacteriaceae, strain $\mathrm{B} 1^{\mathrm{T}}$ was not able to degrade high-molecular-mass carbohydrates like starch or agar (Table 2). Moreover, it showed no proteolytic properties in hydrolysing gelatin, but it was able to grow with peptone as the sole carbon and nitrogen source.

Under strictly anoxic or suboxic conditions, strain $\mathrm{B} 1^{\mathrm{T}}$ showed no production of the gaseous nitrogen compounds $\mathrm{N}_{2}, \mathrm{~N}_{2} \mathrm{O}$ or $\mathrm{NO}$ (analysed by mass spec- trometry) when incubated in liquid nutrient broth. Nitrate was not consumed and not reduced to nitrite. Nevertheless, strain $\mathrm{B} 1^{\mathrm{T}}$ grew in liquid nutrient broth under anoxic conditions. Aerobic growth was tested in Hugh \& Leifson's O/F medium and Leifson's modified O/F medium (Smibert \& Krieg, 1994). Strain B1 ${ }^{\mathrm{T}}$ only showed growth and weak acid production with the modified $\mathrm{O} / \mathrm{F}$ medium, which, in contrast to Hugh \& Leifson's medium, contains artificial seawater (Smibert \& Krieg, 1994). This indicates that this bacterium is capable of metabolizing fructose with acid production and that it requires the salts of artificial seawater.

\section{Fatty acid profile}

The composition of the fatty acid profile of strain $\mathrm{B} 1^{\mathrm{T}}$ was as follows: $13: 1(1 \cdot 50 \%)$, i15:1 (16.29\%), a $15: 1$ $(0.55 \%)$, i15:0 (15.52\%), a15:0 (2.40\%), 15:0 $(1.08 \%), 2-\mathrm{OH}$ i15:0 and $16: 1 \omega 7 c(2.54 \%), 16: 0$ $(1 \cdot 10 \%)$, 3-OH i15:0 (4.88\%), 2-OH 15:0 (0.46\%), i17: $1 \omega 9 c(1 \cdot 01 \%), 3-\mathrm{OH} 15: 0(0 \cdot 62 \%), 3-\mathrm{OH}$ i16:0 $(2 \cdot 73 \%), 3-\mathrm{OH} 16: 0(2.91 \%), 3-\mathrm{OH}$ i17:0 $(28.70 \%)$, 2-OH 17:0 (2.83\%) and unidentified fatty acids $(14.86 \%)$. The fatty acid profile of strain $\mathrm{B} 1^{\mathrm{T}}$ is characterized by high proportions of the branched fatty acids 13-methyl tetradecenoic acid, 13-methyl tetradecanoic acid and 3-hydroxy-15-methyl hexadecanoic acid, which represented $60.51 \%$ of the total fatty acids. It is important to note that $72.1 \%$ of the whole-cell fatty acids were of the branched type.

\section{DNA base composition}

The $\mathrm{G}+\mathrm{C}$ content of the DNA is $41.4 \mathrm{~mol} \%$, as determined by the HPLC method.

\section{Phylogeny}

The phylogenetic relationships of the strain were examined using the almost complete 16S rDNA sequence $(1426 \mathrm{bp})$ determined by the Sequence Laboratories Göttingen. A comparison of the sequence with sequences from GenBank demonstrated that strain $\mathrm{B} 1^{\mathrm{T}}$ belongs to the family Flavobacteriaceae within the phylum 'Cytophaga-FlavobacteriumBacteroides'. This was confirmed by whole-cell hybridization with the 16S rRNA-directed oligonucleotide probe CF319a (target position 319-336, 5'-TGGTCCGTGTCTCAGTAC-3') developed by Manz et al. (1996).

The dendrogram shown in Fig. 3 was constructed by the neighbour-joining method (Saitou \& Nei, 1987). It shows that the branch containing Zobellia uliginosa and strain $\mathrm{B} 1^{\mathrm{T}}$ is related to the other members of the Flavobacteriaceae. The similarity between the $16 \mathrm{~S}$ rDNA sequences of Zobellia uliginosa and strain $\mathrm{B}^{\mathrm{T}}$ was $90.72 \%$. The other members of the Flavobacteriaceae are even more distantly related to strain 
Table 2. Phenotypic characteristics that differentiate strain $B 1^{\top}$ from other halophilic members of the Flavobacteriaceae

Taxa are identified as: 1, Muricauda ruestringensis sp. nov. B1 ${ }^{\mathrm{T}} ; 2$, Zobellia uliginosa; 3, Cellulophaga lytica; 4, [Flexibacter] maritimus; 5, Salegentibacter salegens. Characters are scored as: +, positive reaction; -, negative reaction; NA, no data available. Data were taken from this study (strain B1 ${ }^{\mathrm{T}}$ ), Reichenbach $(1989 \mathrm{~b})$ (Zobellia uliginosa, Cellulophaga lytica and [Flexibacter] maritimus) and Dobson et al. (1993) and McCammon \& Bowman (2000) (Salegentibacter salegens). All taxa are oxidase-positive.

\begin{tabular}{|c|c|c|c|c|c|}
\hline Character & 1 & 2 & 3 & 4 & 5 \\
\hline Cell length $(\mu \mathrm{m})$ & $1 \cdot 1-2 \cdot 7$ & $1 \cdot 2-4 \cdot 0$ & $1 \cdot 5-3 \cdot 5$ & $2 \cdot 0-5 \cdot 0$ & $1 \cdot 2-11 \cdot 5$ \\
\hline Cell width $(\mu \mathrm{m})$ & $0 \cdot 3-0 \cdot 6$ & 0.4 & $0 \cdot 4$ & $0 \cdot 4$ & $0 \cdot 5-0 \cdot 8$ \\
\hline Pigment colour & Yellow & Golden yellow & Bright yellow & Yellow-orange & Yellow \\
\hline Flexirubin reaction & - & + & - & NA & - \\
\hline Gliding motility & + & + & + & + & NA \\
\hline Growth on peptone alone & + & + & + & + & NA \\
\hline \multicolumn{6}{|l|}{ Hydrolysis of: } \\
\hline Gelatin & - & + & + & + & + \\
\hline Starch & - & + & + & - & + \\
\hline Cellulose (filter paper) & - & - & - & - & NA \\
\hline Agar & - & + & + & NA & - \\
\hline \multicolumn{6}{|l|}{ Production of: } \\
\hline lndole & - & - & NA & - & NA \\
\hline $\mathrm{H}_{2} \mathrm{~S}$ & - & - & + & - & - \\
\hline Nitrate reduced & - & + & - & + & + \\
\hline Strict aerobe & - & + & + & + & + \\
\hline Facultative anaerobe & + & - & - & - & - \\
\hline Catalase & - & + & + & + & + \\
\hline Optimum temperature for growth $\left({ }^{\circ} \mathrm{C}\right)$ & $20-30$ & $20-30$ & $22-30$ & 30 & NA \\
\hline Highest $\mathrm{NaCl}$ concentration tolerated $(\%)$ & 9 & NA & 6 & NA & 20 \\
\hline DNA $\mathrm{G}+\mathrm{C}$ content $(\mathrm{mol} \%)$ & 41 & 42 & 33 & 31 & 41 \\
\hline
\end{tabular}

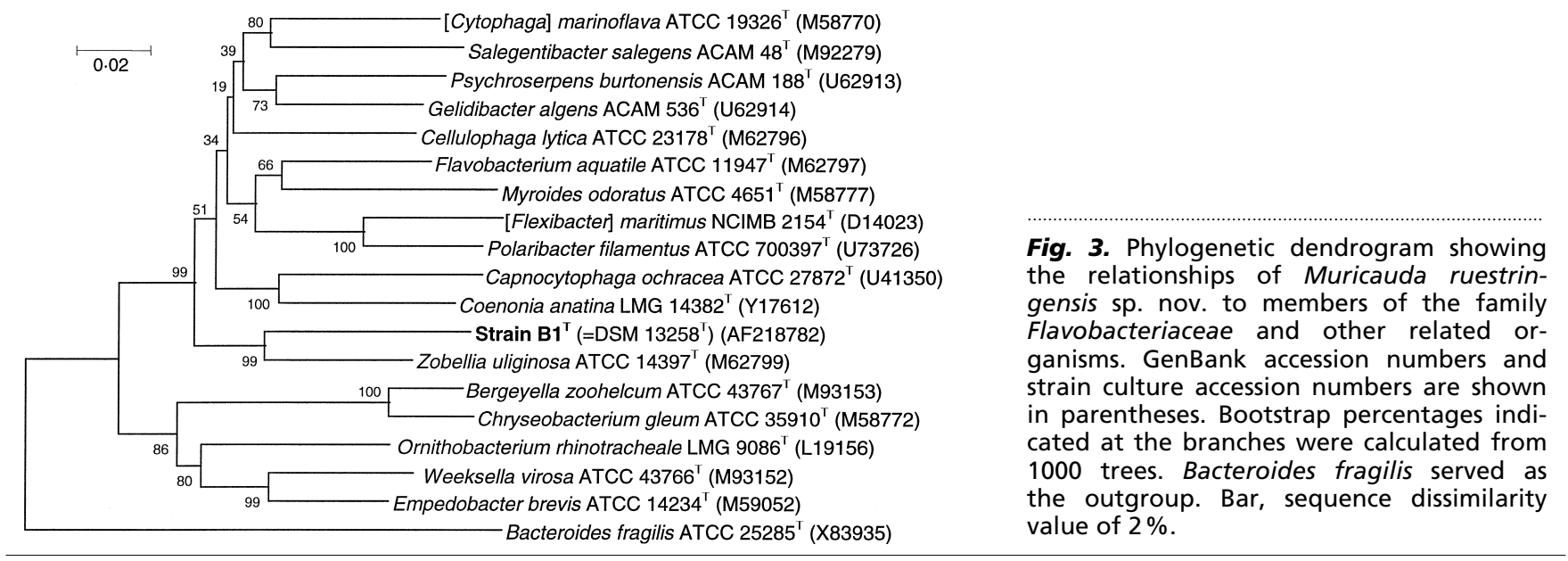

$\mathrm{B} 1^{\mathrm{T}}$, with less than $86 \%$ sequence similarity (the second closest relative is Gelidibacter algens, 86.05\%).

\section{DISCUSSION}

The most striking results of the phenotypic analysis are the appendages of strain $\mathrm{B} 1^{\mathrm{T}}$ (Figs 1 and 2), which are formed as a continuum of the outer membrane. These appendages are morphologically similar to those described for Flavobacterium aquatile strain ATCC $11947^{\mathrm{T}}$ (Thomson et al., 1981) and for Flexibacter strain BH3 (Humphrey et al., 1979). Humphrey et al. (1979) revealed that the vesicular-tubular material was derived from the lipopolysaccharide membrane and the authors speculated as to whether the extruded material had any function in gliding, adhesion or slime 
excretion. The only member of the Flavobacteriaceae that possesses flagella is Polaribacter irgensii, but motility has never been observed in wet mounts (Gosink et al., 1998). In hanging-drop preparations or in wet mounts, strain $\mathrm{B}^{\mathrm{T}}$ also did not show motility. We observed neither a swimming motility nor a gliding motility as defined by Henrichsen (1972). Thus, the function of the appendages still has to be investigated in detail. We assume the connection of cells with each other as one possible function of the appendages (Fig. 1a). This may explain why the strain forms flocks when growing in PAC medium. When cells were provided with surfaces for growth, such as glass beads, they seemed to prefer colonizing these surfaces to living freely in the medium. Adhesion to surfaces and flock formation may be a selective advantage for cells growing in intertidal habitats, which are characterized by considerable water currents. Marshall et al. (1971) suggested that extracellular material may play a role in the initial contact with a surface by providing a means of polymer bridging between the cell and the surface. This may support our assumption.

The phylogenetic tree (Fig. 3) reveals a distant relationship between Zobellia uliginosa (formerly [Cellulophaga] uliginosa, Barbeyron et al., 2001 ; [Cytophaga] uliginosa, Bowman, 2000) and strain $\mathrm{B}^{\mathrm{T}}$. The stability of this group was supported by the high bootstrap value of $98 \%$. However, the rather low sequence similarity of $90.7 \%$ argues in favour of classifying these two organisms into separate genera. In addition, these strains are morphologically and physiologically different. As shown in Table 2, strain $\mathrm{B} 1^{\mathrm{T}}$ is a facultatively anaerobic organism, while Zobellia uliginosa has a strictly aerobic respiratory metabolism.

Strain $\mathrm{B} 1^{\mathrm{T}}$ is well adapted to the environment from which it was isolated. The intertidal mud-flat zone of the North Sea is characterized by a sharp drop from oxic to anoxic conditions in the sediment within a few centimetres. Thus, the ability to switch between an aerobic and an anaerobic metabolism is very useful. In addition, its wide temperature range for growth indicates a good adaptation of strain $\mathrm{B}^{\mathrm{T}}$ to the environmental conditions of the mud-flat zone. The temperature changes in summer occur cyclically with the tides and lie between about $17^{\circ} \mathrm{C}$ when the flats are covered with water and $60{ }^{\circ} \mathrm{C}$ when they dry out and are exposed to the sun.

In contrast to Zobellia uliginosa, strain $\mathrm{B} 1^{\mathrm{T}}$ is not able to reduce nitrate, has no pigment of the flexirubin type and is not able to degrade high-molecular-mass carbohydrates such as starch or agar. In common with all members of the emended family Flavobacteriaceae (Bernardet et al., 1996), it is not able to degrade crystalline cellulose (filter paper).

When supplied with a mixture of amino acids (Casamino acids as given in PAC medium) or a mixture of 19 amino acids (Table 1), strain $\mathrm{B} 1^{\mathrm{T}}$ showed good growth. However, with mixtures of only four amino acids, with alanine or arginine as substrate, growth was considerably weaker. This organism presumably prefers to use some specific amino acids for growth; this remains to be tested in further studies. The bacterium is able to grow anaerobically when supplied with peptone and yeast extract. It would be quite interesting to determine whether strain $\mathrm{B} 1^{\mathrm{T}}$ ferments amino acids by the Stickland reaction (Buckel, 1991), which would explain why it showed good growth with a mixture of amino acids but weak growth with single amino acids. The absence of acid fermentation when strain $\mathrm{B}^{\mathrm{T}}$ was growing anaerobically with peptone and yeast extract (data not presented) may support this assumption, since the Stickland reaction is characterized by the production of $\mathrm{NH}_{4}^{+}$and an acid, resulting in a neutral $\mathrm{pH}$. This has to be investigated further.

The fact that strain $\mathrm{B} 1^{\mathrm{T}}$ is able to use sugars and amino acids for growth but not hexadecane, even though the strain was isolated from a culture with hexadecane as the sole source of carbon, demonstrates that it probably profits from the lysis or from secondary products like surfactants of other cells in the hexadecanedegrading community.

Kaneda (1991) reported the existence of two different fatty acid families, a straight-chain fatty acid family and a branched-chain fatty acid family. Bacteria with the straight-chain membrane system usually require unsaturated fatty acids for growth, while this is not the case for bacteria with the branched-chain membrane system. Strain $B 1^{T}$ has the latter membrane system. It possesses extremely large proportions of branchedchain fatty acids $(72 \cdot 1 \%$ of the whole-cell fatty acids). This has also been reported for several phylogenetic relatives of strain $\mathrm{B} 1^{\mathrm{T}}$, e.g. [Cytophaga] latercula, with $88.4 \%$ branched-chain fatty acids, Gelidibacter algens (71.4\%), Cellulophaga lytica (formerly [Cytophaga] lytica) $(70.9 \%$; Bowman et al., 1998) and Capnocytophaga ochracea (83.0 \% ; Vandamme et al., 1996). Comparison of the fatty acid profile of strain $\mathrm{B} 1^{\mathrm{T}}$ with those of other members of the Flavobacteriaceae (Bowman et al., 1998; Bowman, 2000) reveals that the nearest relative is Cellulophaga lytica, which has almost the same major fatty acid profile. This clearly confirms that strain $\mathrm{B} 1^{\mathrm{T}}$ belongs to the family Flavobacteriaceae. Moreover, according to the fatty acid profile, this strain seems to be closely related to the genus Cellulophaga, members of which, however, have quite different physiological traits (Table 2). Furthermore, the phylogenetic data do not support such a classification.

To sum up, strain $\mathrm{B} 1^{\mathrm{T}}$ cannot be assigned phylogenetically to an existing genus. Its nearest relative, Zobellia uliginosa, and members of the other genera of the Flavobacteriaceae exhibit distinct characteristics that are not shared completely by the novel strain. Therefore, we propose that the novel strain $\mathrm{B} 1^{\mathrm{T}}$ belongs to a new genus and species within the family Flavobacteriaceae, for which we propose the name Muricauda ruestringensis gen. nov., sp. nov. 


\section{Description of Muricauda gen. nov.}

Muricauda (Mu'ri.cau.da. L. masc. gen. n. muris of the mouse; L. fem. n. cauda the tail; N.L. fem. n. Muricauda tail of the mouse, referring to the cellular appendages observed on some cells).

Gram-negative, rod-shaped cells. Facultatively anaerobic. Cells can grow optimally over a mesophilic temperature range between 20 and $30{ }^{\circ} \mathrm{C}$. Seawater is required for growth. The fatty acid profile is characterized by large amounts of branched fatty acids. According to $16 \mathrm{~S}$ rDNA analysis and binding of the rRNA to the oligonucleotide CF319a, Muricauda is a member of the family Flavobacteriaceae within the phylum 'Cytophaga-Flavobacterium-Bacteroides'.

\section{Description of Muricauda ruestringensis sp. nov.}

Muricauda ruestringensis (rue.strin'gen.sis. N.L. adj. ruestringensis of Rüstringen, referring to the former village of Rüstringen, which was destroyed by a tidal wave in 1362, near the site of which the type strain was isolated).

The cells are Gram-negative rods, 0.3-0.6 $\mu \mathrm{m}$ wide and $1 \cdot 1-2 \cdot 7 \mu \mathrm{m}$ long. Cells of older cultures (3-4 d) are characterized by long and relatively thick (20-30 nm) appendages, which seem to be used to connect cells to each other. Cells are non-motile in hanging-drop preparations. Colonies are circular, $0.5-1.0 \mathrm{~mm}$ in diameter and yellow-pigmented. The strain has no flexirubin-type pigment. The temperature for growth ranges from 8 to $40^{\circ} \mathrm{C}$, with optimal growth at 20-30 ${ }^{\circ} \mathrm{C}$. Strain $\mathrm{B} 1^{\mathrm{T}}$ requires the salt components of artificial seawater and grows at $\mathrm{NaCl}$ concentrations of $0.5-9.0 \%(\mathrm{w} / \mathrm{v})$, with an optimum at $3 \%(\mathrm{w} / \mathrm{v}) . M$. ruestringensis is a facultatively anaerobic organism, being able to grow anaerobically with complex carbon sources. No ability to break down high-molecularmass carbohydrates like starch, agar or crystalline cellulose is observed. The strain shows no denitrifying properties and no proteolytic properties in hydrolysing gelatin, but does show good growth with peptone as the sole carbon and nitrogen source. It is catalasenegative but oxidase-positive. Major cellular fatty acids are $\mathrm{i} 15: 1, \mathrm{i} 15: 0$ and $3-\mathrm{OH}$ i17:0. The $\mathrm{G}+\mathrm{C}$ content of the DNA is $41 \mathrm{~mol} \%$.

The type strain is strain $\mathrm{B} 1^{\mathrm{T}}\left(=\mathrm{DSM} 13258^{\mathrm{T}}=\mathrm{LMG}\right.$ $\left.19739^{\mathrm{T}}\right)$.

\section{ACKNOWLEDGEMENTS}

We would like to thank Professor Dr Trüper for support in the etymologies of the genus and species names, Professor Dr Wünsche for determining the $\mathrm{G}+\mathrm{C}$ content and $\mathrm{Dr}$ Härtig for the fatty acid analysis. Thanks are due to KarlHeinz Plate for doing the mass spectrometry, to Ellruth Müller for preparing ultrathin sections and especially to Uwe Maschmann and Babara Brunies for their technical assistance.

\section{REFERENCES}

Altschul, S. F., Madden, T. L., Schäffer, A. A., Zhang, J., Zhang, Z., Miller, W. \& Lipman, D. J. (1997). Gapped BLAST and PSI-BLAST: a new generation of protein database search programs. Nucleic Acids Res 25, 3389-3402.

Barbeyron, T., L'Haridon, S., Corre, E., Kloareg, B. \& Potin, P. (2001). Zobellia galactanovorans gen. nov., sp. nov., a marine species of Flavobacteriaceae isolated from a red alga, and classification of [Cytophaga] uliginosa (ZoBell and Upham 1944) Reichenbach 1989 as Zobellia uliginosa gen. nov., comb. nov. Int J Syst Evol Microbiol 51, 985-997.

Bernardet, J.-F., Segers, P., Vancanneyt, M., Berthe, F., Kersters, K. \& Vandamme, P. (1996). Cutting a Gordian knot: emended classification and description of the genus Flavobacterium, emended description of the family Flavobacteriaceae, and proposal of Flavobacterium hydatis nom. nov. (basonym, Cytophaga aquatilis Strohl and Tait 1978). Int J Syst Bacteriol 46, 128-148.

Bowman, J. P. (2000). Description of Cellulophaga algicola sp. nov., isolated from the surfaces of Antarctic algae, and reclassification of Cytophaga uliginosa (ZoBell and Upham 1944) Reichenbach 1989 as Cellulophaga uliginosa comb. nov. Int J Syst Evol Microbiol 50, 1861-1868.

Bowman, J. P., McCammon, S. A., Brown, J. L., Nichols, P. D. \& McMeekin, T. A. (1997a). Psychroserpens burtonensis gen. nov., sp. nov., and Gelidibacter algens gen. nov., sp. nov., psychrophilic bacteria isolated from Antarctic lacustrine and sea ice habitats. Int J Syst Bacteriol 47, 670-677.

Bowman, J. P., McCammon, S. A., Brown, M. V., Nichols, P. D. \& McMeekin, T. A. (1997b). Diversity and association of psychrophilic bacteria in Antarctic sea ice. Appl Environ Microbiol 63, 3068-3078.

Bowman, J. P., McCammon, S. A., Lewis, T., Skerratt, J. H., Brown, J. L., Nichols, D. S. \& McMeekin, T. A. (1998). Psychroflexus torquis gen. nov., sp. nov., a psychrophilic species from Antarctic sea ice, and reclassification of Flavobacterium gondwanense (Dobson et al. 1993) as Psychroflexus gondwanense gen. nov., comb. nov. Microbiology 144, 1601-1609.

Bruns, A. \& Berthe-Corti, L. (1998). In situ detection of bacteria in continuous-flow cultures of seawater sediment suspensions with fluorescently labelled rRNA-directed oligonucleotide probes. Microbiology 144, 2783-2790.

Bruns, A. \& Berthe-Corti, L. (1999). Fundibacter jadensis gen. nov., sp. nov, a new slightly halophilic bacterium, isolated from intertidal sediment. Int $J$ Syst Bacteriol 49, 441-448.

Buckel, W. (1991). Ungewöhnliche Chemie bei der Fermentation von Aminosäuren durch anaerobe Bakterien. BIOforum 1, 7-19.

Budzikiewicz, H. (1998). Massenspektrometrie, Eine Einführung. Weinheim: Wiley-VCH.

Dobson, S. J., Colwell, R. R., McKeekin, T. A. \& Franzmann, P. D. (1993). Direct sequencing of the polymerase chain reactionamplified 16S rRNA gene of Flavobacterium gondwanense sp. nov. and Flavobacterium salegens sp. nov., two new species from a hypersaline Antarctic lake. Int J Syst Bacteriol 43, 77-83.

Fautz, E. \& Reichenbach, H. (1980). A simple test for flexirubintype pigments. FEMS Microbiol Lett 8, 87-91.

Gauthier, M. J., Lafay, B., Christen, R., Fernandez, L., Acquaviva, M., Bonin, P. \& Bertrand, J.-C. (1992). Marinobacter hydrocarbonoclasticus gen. nov., sp. nov., a new, extremely halotolerant, hydrocarbon-degrading marine bacterium. Int J Syst Bacteriol 42, 568-576. 
Glöckner, F. O., Fuchs, B. M. \& Amann, R. (1999). Bacterioplankton compositions of lakes and oceans: a first comparison based on fluorescence in situ hybridization. Appl Environ Microbiol 65, 3721-3726.

Gosink, J. J., Woese, C. R. \& Staley, J. T. (1998). Polaribacter gen. nov., with three new species, $P$. irgensii sp. nov., $P$. franzmannii sp. nov. and $P$. filamentus sp. nov., gas vacuolate polar marine bacteria of the Cytophaga-Flavobacterium-Bacteroides group and reclassification of 'Flectobacillus glomeratus' as Polaribacter golmeratus comb. nov. Int J Syst Bacteriol 48, 223-235.

Henrichsen, J. (1972). Bacterial surface translocation: a survey and a classification. Bacteriol Rev 36, 478-503.

Humphrey, B. A., Dickson, M. R. \& Marschall, K. C. (1979). Physicochemical and in situ observations on the adhesion of gliding bacteria to surfaces. Arch Microbiol 120, 231-238.

Johansen, J. E., Nielsen, P. \& Sjøholm, C. (1999). Description of Cellulophaga baltica gen. nov., sp. nov. and Cellulophaga fucicola gen. nov., sp. nov. and reclassification of [Cytophaga] lytica to Cellulophaga lytica gen. nov., comb. nov. Int J Syst Bacteriol 49, 1231-1240.

Jukes, T. H. \& Cantor, C. R. (1969). Evolution of protein molecules. In Mammalian Protein Metabolism, vol. 3, pp. 21-132. Edited by H. N. Munro. New York: Academic Press.

Kaneda, T. (1991). Iso- and anteiso-fatty acids in bacteria: biosynthesis, function, and taxonomic significance. Microbiol Rev 55, 288-302.

Kumar, S., Tamura, K. \& Nei, M. (1994). MEGA: Molecular Evolutionary Genetics Analysis software for microcomputers. Comput Appl Biosci 10, 189-191.

Levring, T. (1946). Some culture experiments with Ulva and artificial seawater. Kungl Fysiografiska Sällsk Lund Förhandlingar 16, 45-56.

Llobet-Brossa, E., Rosselló-Mora, R. \& Amann, R. (1998). Microbial community composition of Wadden Sea sediments as revealed by fluorescence in situ hybridization. Appl Environ Microbiol 64, 2691-2696.

McCammon, S. A. \& Bowman, J. P. (2000). Taxonomy of Antarctic Flavobacterium species: description of Flavobacterium gillisiae sp. nov., Flavobacterium tegetincola sp. nov. and Flavobacterium xanthum sp. nov., nom. rev. and reclassification of [Flavobacterium] salegens as Salegentibacter salegens gen. nov., comb. nov. Int J Syst Evol Microbiol 50, 1055-1063.

Manz, W., Amann, R., Ludwig, W., Vancanneyt, M. \& Schleifer, K.-H. (1996). Application of a suite of $16 \mathrm{~S}$ rRNA-specific oligonucleotide probes designed to investigate bacteria of the phylum cytophaga-flavobacter-bacteroides in the natural environment. Microbiology 142, 1097-1106.

Marshall, K. C., Stout, R. \& Mitchell, R. (1971). Mechanism of the initial events in the sorption of marine bacteria to surfaces. $J$ Gen Microbiol 68, 337-348.

Mesbah, M., Premachandran, U. \& Whitman, W. B. (1989). Precise measurement of the $\mathrm{G}+\mathrm{C}$ content of deoxyribonucleic acid by high-performance liquid chromatography. Int J Syst Bacteriol 39, 159-167.
Muyzer, G., Teske, A., Wirsen, C. O. \& Jannasch, H. W. (1995). Phylogenetic relationships of Thiomicrospira species and their identification in deep-sea hydrothermal vent samples by denaturing gradient gel electrophoresis of $16 \mathrm{~S} \mathrm{rDNA}$ fragments. Arch Microbiol 164, 165-172.

Nakagawa, Y. \& Yamasato, K. (1996). Emendation of the genus Cytophaga and transfer of Cytophaga agarovorans and Cytophaga salmonicolor to Marinilabilia gen. nov.: phylogenetic analysis of the Flavobacterium-Cytophaga complex. Int J Syst Bacteriol 46, 599-603.

Reichenbach, H. (1989a). Order I. Cytophagales Leadbetter 1974, 99 ${ }^{\mathrm{AL}}$. In Bergey's Manual of Systematic Bacteriology, vol. 3, pp. 2011-2013. Edited by N. R. Krieg \& J. G. Holt. Baltimore: Williams \& Wilkins.

Reichenbach, H. (1989b). Genus I. Cytophaga Winogradsky 1929, 577, ${ }^{\mathrm{AL}}$ emend. In Bergey's Manual of Systematic Bacteriology, vol. 3, pp. 2015-2050. Edited by N. R. Krieg \& J. G. Holt. Baltimore: Williams \& Wilkins.

Reichenbach, H. (1992). The order Cytophagales. In The Prokaryotes, vol. 4, pp. 3631-3675. Edited by A. Balows and others. New York: Springer.

Saitou, N. \& Nei, M. (1987). The neighbor-joining method: a new method for reconstructing phylogenetic trees. Mol Biol Evol 4, 406-425.

Sambrook, J., Fritsch, E. F. \& Maniatis, T. (1989). Molecular Cloning : a Laboratory Manual. Cold Spring Harbor, NY: Cold Spring Harbor Laboratory.

Schlegel, H. G. (1992). Allgemeine Mikrobiologie, 7th edn. Weinheim: Georg Thieme Verlag.

Smibert, R. M. \& Krieg, N. R. (1994). General characterization. In Methods for General and Molecular Bacteriology, pp. 607-654. Edited by P. Gebhardt, R. G. E. Murray, W. A. Wood \& N. R. Krieg. Washington, DC: American Society for Microbiology.

Thompson, J. D., Higgins, D. G. \& Gibson, T. J. (1994). CLUSTAL $\mathrm{W}$ : improving the sensitivity of progressive multiple sequence alignment through sequence weighting, position-specific gap penalties and weight matrix choice. Nucleic Acids Res 22, 4673-4680.

Thomson, K. S., McMeekin, T. A. \& Thomas, C. J. (1981). Electron microscopic observations of Flavobacterium aquatile NCIB 8694 (= ATCC 11947) and Flavobacterium meningosepticum NCTC 10016 (=ATCC 13253). Int J Syst Bacteriol 31, 226-231.

Valentine, R. C., Shapiro, B. M. \& Stadtman, E. R. (1968). Regulation of glutamine synthetase. XII. Electron microscopy of the enzyme from Escherichia coli. Biochemistry 7, 2143-2152.

Vandamme, P., Vancanneyt, M., Van Belkum, A., Segers, P., Quint, W. G. V., Kersters, K., Paster, B. J. \& Dewhirst, F. E. (1996). Polyphasic analysis of strains of the genus Capnocytophaga and Centers for Disease Control group DF-3. Int J Syst Bacteriol 46, 782-791.

Wolkin, R. H. \& Pate, J. L. (1984). Translocation of motile cells of the gliding bacterium Cytophaga johnsonae depends on a surface component that may be modified by sugars. J Gen Microbiol 130, 2651-2669. 